\author{
A. Hafiiak, S. Alyoshin, E. Borodina, A. Diachenko-Bohun
}

Poltava National Technical Yuriy Kondratyuk University, Poltava, Ukraine

\title{
MODERN INFORMATION TECHNOLOGIES AS THE BASIS OF THE EDUCATIONAL INFORMATIZATION PROCESS
}

\begin{abstract}
The article is devoted to the analysis and research of innovative methods of teaching students in the conditions of the development of the information technology industry. Actual problems of professional training of specialists in the conditions of the development of the information society are analyzed and ways of their solution are investigated. Analyzed the role of information technology in higher education institutions. Currently, the main directions in the educational process are the use of automated systems and complexes, expert systems and decision support systems, the development of information technologies on the use of information technologies for modeling various objects and processes. The types of innovative teaching methods using modern technologies have been studied. At this stage they use powerful personal computers, new information and telecommunication technologies. The features of hardware and software for educational purposes are investigated. One of the special means of training is accessibility, the speed of obtaining knowledge at a convenient time, the possibility of an individual rate of knowledge acquisition. The directions of the use of information technology in the educational environment are substantiated.
\end{abstract}

Keywords: software tools, innovative teaching methods, information technologies, pedagogical innovation.

\section{Introduction}

The transforming process of society into a global informational space is based on the specialists' competence, which allows keeping the problem of innovative approaches to the educational processes organization up to date. The main features of the informational society are: increasing role of information in public life, increasing the number of specialists involved in the information technology, growth of information technologies and the role of information technology in public relations; creating a global informational space that provides access to world information resources [1-8].

The education system in modern conditions receives additional requirements for specialists' training skills in the solving of non-standard tasks that is why the leading place in such system takes the innovative methods for preparing students in the higher education system. In this regard, the problems of innovative methods of teaching students in the conditions of the information technology development and information technology industry and their analysis are definitely relevant.

Scientific works analysis. The problems of innovative methods of teaching students in the conditions of information technologies development and information and telecommunication technologies industry and their analysis were researched by many domestic and foreign scientists, where the complexity and multidimensionality of this process is noted [9-13]. Scientists claim that an innovative approach to students learning should be systematic and cover all aspects of educational work in the preparation of future professionals, while the theoretical and practical approaches to the content of education, the new technologies and teaching methods development should be reviewed. V. Andrieiev, M. Zhaldak, Ye. Mashbyts, I. Osmolovska, Yu. Ramskyi, V. Rudenko, I. Pidlasyi, N. Symonenko, and V. Shapkin are engaged in the problem of innovative technologies in the context of vocational training. Professional training general theoretical bases in the context of modern education were studied by V. Bezpalka, S. Honcharenka, O. Dubaseniuk, and P. Saukha.

N. Symonenko believes that during the specialists' preparation in higher education the application of innovative forms and methods should be organically combined with a pragmatic understanding of the training goals and objectives, he notes that innovative methods are reflected in many learning technologies aimed at the development and improvement of educational process and of specialists' preparation in various spheres of modern society life [7, p. 203-204]. According to I. Osmolovska, the basis of innovative educational technologies used in the educational process should be a social order, future specialists' professional interests, individual, personal characteristics of students $[6$, p. 184]. These and other studies make it possible to identify promising directions in the field of information and telecommunication technologies application in the educational process.

Article goal: innovative methods of teaching students analysis in the conditions of the information technologies development and information and telecommunication technologies industry. The actual problems of professional specialists' training are analyzed and ways of their solution are investigated. The types of innovative teaching methods in higher educational institutions are investigated. The role of information and social technologies in education is analyzed. The peculiarities of educational software tools are investigated. The directions of information technologies use in the educational environment are substantiated. The stated goal defined the tasks: to define the concept of pedagogical innovation as innovation in the field of pedagogy; to analyze modern information educational technologies; to identify promising directions in the field of information and telecommunication technologies application in the educational process (Fig. 1).

The theoretical and methodological basis of the research was the work of leading domestic and foreign 
scientists and specialists in the field of improving and analyzing innovative teaching students' methods. General scientific methods were used $\mathrm{n}$ the work: comparison, generalization, formalization, analysis and synthesis.

The problem of computer technology use in the professional students' training of higher technical education institutions is closely linked to the process of education's informatization. Trends in the modern society development, its expressed informatization explain the need for the increasing use of information technology in the field of education.

Education's informatization is a process of providing the sphere of education with the theory and practice of modern information technologies use, which is focused on the psychological and pedagogical purpose of education realization.

The word "technology" has Greek roots and in translation means science, a set of methods and techniques for the processing of raw materials, semi-finished products, goods and its transformation into consumer items. Modern meaning of this word includes the application of scientific and engineering knowledge for solving practical problems. In this case, information and telecommunication technologies can be considered such technologies, which are aimed at processing and transformation of data.

Information and telecommunication technologies (ICTs) are a generalized concept that describes various methods, ways and algorithms for collecting, storing, processing, presenting and transmitting data. This definition purposely does not include the word "the use". The use of information and telecommunication technologies allows us to talk about another technology the technology of the information and telecommunication technologies use in education, medicine, military affairs and many other fields of human activity, which is part of the informatization technologies. Each of these industries imposes its limitations and features on the information technology [12-25].

The system of general and vocational education, in spite of the expressed need for wider introduction of high educational technologies, is a catalyst for the process of society informatization, a tool for the formation of person's information culture, professionals' training of new formation. In Ukraine, in a fairly short period of time, there have been cardinal transformations, instead of the traditional education system, another system comes into existence, which has a setup for the formation of well-developed, creative person, adaptable to constants changes in the environment, able to orient in the flow of information, continuously develop its skills [26-29]. Implementation process analysis and use of computer technology in the educational process allows distinguishing three stages of informatization.

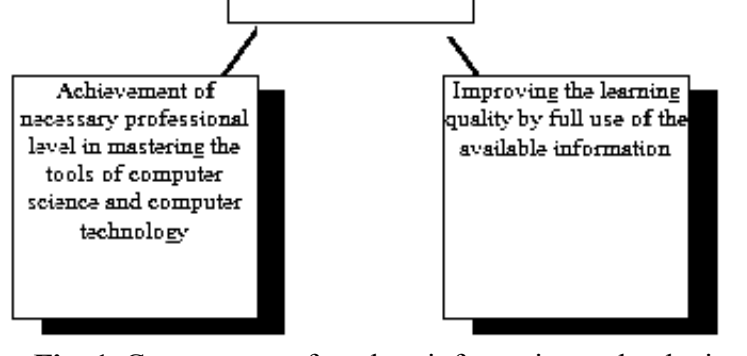

Fig. 1. Components of modern information technologies as the basis of informatization of education process

The second stage of education's informatization (mid 70-ies) is associated with the appearance of more powerful computers, software that has a convenient interface, and is characterized primarily by the use of human-to-computer interaction. Students as subjects of the educational process, for the first time, were able to work on a computer, interact with models - "users" of real objects and, most importantly, to manage the objects of study. In the education automated learning, knowledge control and learning management systems are increasingly used. The third, modern, stage of education's informatization is characterized by the use of powerful personal computers, high-speed large-capacity storage, new information and telecommunication technologies, multimedia technologies and virtual reality, as well as philosophical comprehension of the informatization process, and its social consequences.

Currently, the education system has developed the main directions of computer technology application in the educational process: the use in the learning process of automated systems and complexes, expert systems and decision support systems; development of information technologies oriented at further application in professional activity; the use of information technology as a didactic tool for the simulation of various objects and processes; increasing the creative component of educational and research activities.

Summarizing the scientific positions advocating the need for distance learning, we consider it possible to highlight the following aspects of positive aspects:

- availability, speed of knowledge obtaining, convenient time, without unnecessary economic and resource costs, the possibility of an individual pace of knowledge obtaining;

- humanization of educational space, which means access to education is received by people with special 
needs, poor; distance form allows to combine continuous education with work, etc .;

- increasing global demand for education in a globalized economy;

- the possibility of profit: venture capital opened the distance education, which became a great business;

- the rate of innovation spreading, which "pushes" the market; accordingly, the amount of money invested in information technology will become bigger.

Characteristic features of distance education are flexibility (at a convenient time and in a convenient place), modularity (a separate course creates a complex idea of a particular subject area, which allows a set of independent module modules to form a curriculum that meets individual or group needs), economic, technological ability, social equality, internationality (the opportunity to receive education in educational institutions of foreign countries, without leaving their country and provide educational services to abroad), the new role of teacher, quality and so on [10].

Conceptual approaches to future specialists' training are based on the results of studying and forecasting the structure of social and production activities of specialists with higher education in the field of informational activity in accordance with the needs of the labor market, according to the specialist's requirements, according to which the content of education in this field is determined, that means that the concept of training a specialist is based on the model of a specialist development, the basis of which is the system; it is a social need, educational qualification characteristic (skills), educational professional program (knowledge), diagnosing means in the interrelationship and interdependence of all its components, combined with the definition of pedagogical conditions of specialists' training and the relevant practical approaches to their implementation.

Nowadays there is the emergence of new approaches, which occurs with some complications. Therefore, the attention should be devoted to this problem in particular. The term "informational society" was created by professor Yu. Khaiashi, who formulated its main paradigms concerning the formation of public relations on the basis of high-tech informational networks, that are operating on a global scale and are recognizing information as the basic social value of society. Capital is inferior to information, knowledge, and intelligence [10].

The informational society is the most developed technological production method of human civilization that arises as a result of the informational and computer revolution and is based on information technology, "intelligent" computers, automatization and robotization of all spheres and branches of economy and management, the only newest integrated system of communication. Therefore, the main features of the information society are the following: the transformation of information into the most important economic resource that is global in nature and provides with increased efficiency, growth of competitiveness and innovative development of business entities; increasing influence of information on all spheres of human life, transforming it into the public consumption subject; intensive formation of the informational sector of the economy, which occupies a dominant position in a new society; the transformation of the information sphere into the foundation, the basis of all types of economic activity. The indicated signs illustrate the importance of the education sphere. So, if the previous industrial sphere recognized the production sphere as a basis and skilled labor, the globalized society determines education as the main feature of person and society's success. The informational society and education development are mutually complementary, mutually important phenomena. The basis of modern high-quality education is its informatization as a set of interrelated organizational, legal, political, socioeconomic, scientific and technical, production processes, aimed at creating conditions for meeting the informational needs of citizens and society through the development and use of informational systems, networks, resources and technologies that are based on the application of modern computing and communication technology [9].

The level of teacher's readiness for distance education, the development of proper technological programs and their implementation at the university level, the accordance of scientific and methodological and technical support. Teachers of an educational institution must adhere to special requirements: they must have knowledge of the purpose, features, functioning of the telecommunication network; storage conditions and information transmission in the network; organization and implementation's features of telecommunication projects, teleconferences; methodical foundations for organizing the work of teachers and students in the network; the basic rules of user behavior in the network, the basis of telecommunication etiquette. Teachers and coordinators should be able to: work with e-mail, teleconferences, network information services; select and process information received from the network; to search information in the network; to prepare the information for the transmission in the network using a text editor, graphic editor and necessary services (archives, encoders); organize, develop and conduct a network project, teleconference [6, c. 371].

Secondly, a high level of information culture of educational services consumers. This is the possibility of students to use technical means. The indicated problem is connected with the more general informational culture of society. Today, significant progress has been made in Ukraine regarding the possibility of access to the Internet, but still such availability should be accompanied by computer literacy of users. An important trend today is that in the developed countries of the world a new, informational image of people is formed. The fact is that the informational space of society quickly creates people's new skills, stereotypes of behavior, new cultural demands and even new values. The new information environment changes the person himself, the whole lifestyle and professional activity. The amount of information increases exponentially in the Internet, "overdose of information" leads to misinformation [7, c. 7]. 
The informational global environment affects all spheres of public relations, but the educational sphere gets a dominant influence. It is stated that the classical forms of education should be conformed and adapted according to the requirements of the informational society. The main displays of education's informatization are defined: new means of obtaining knowledge, innovation of technical resources for obtaining information; strengthening of internal and international communication of the educational and scientific sphere; the formation of a new content of education and new forms of education, including distance education and virtual universities.

\section{Conclusions}

One of the characteristic features of educational environment is the ability of students and teachers to freely access structured teaching materials and multimedia complexes. An opportunity for personal development and professional growth is important for students, that is why today the need to use innovative teaching methods in the development of information and telecommunication technologies is growing. One of the definitions of the informational educational environment is formulating its understanding as an information system that integrates with the help of network technologies, software and hardware, organizational, methodological and mathematical support, aimed at increasing the efficiency and accessibility of the educational process of specialists' training.

The use of innovative teaching methods in the development of information and telecommunication technologies in the educational process of higher education provides the opportunity to significantly improve the quality of future specialists' training. The necessity of introducing innovative teaching methods in the conditions of the credit-module system in the process of professional specialists' training, using modern technological capabilities, requires further scientific developments and implementation.

\section{REFERENCES}

1. Aristova I.V. State information policy: organizational and legal aspects / I.V. Aristova // Economic and Legal Library [Electronic resource]. - Access mode: http://www.pravo.vuzlib.org/ book_z1189_page_27.html/

2. Lepa N.N. Информационные технологии анализа данных / N.N. Lepa, R.N. Lepa, N.S. Tkachenko // Mathematical Models and Information Technologies in Socio-Economic and Ecological Systems: Materials of the Second International Conference. - Luhansk: Publishisher East Ukrainian National University, 2010. - P. 196-199.

3. Lepa R.N. Информационные технологии в принятии управленческих решений / R.N. Lepa, Yu.Yu. Pyshchenko // Economic problems and prospects for the stabilization of Ukraine's economy. - Donetsk: IIE NAS Ukraine, 2010. - P. 338351.

4. Meliukhyn I.S. Forms of state regulation of informatization processes / I.S. Meliukhyn // [Electronic resource]. - Access mode: http://emag.iis.ru/arc/infosoc/emag.nsf/BPA/07a0d724f36c7688c3257711003e9e95.

5. Ovcharov S. Actual problems of professional teachers of informatics training / S. Ovcharov // Collection of scientific works PNPU. Sections: Pedagogical sciences. - Poltava: PNPU, 2011. Ed. 2. - P. 73-77.

6. Osmolovskaia I.M. Innovation and pedagogical practice / I.M. Osmolovskaia // Public education. - 2010. - № 6. - P. 182-188.

7. Symonenko N.N. Management of educational services using innovative teaching methods / N.N. Symonenko // Pacific State University Bulletin. - 2012. - № 2. - P. 201-206.

8. Formation of English language skills of professional communication with the use of the latest information technologies [Electronic resource]. - Access mode: http://osvita.ua/school/lessons summary/ edu technology/ 24423.

9. About the Concept of the National Program of Informatization: Law of Ukraine from 04.02.1998 № 75/98-BP // Verkhovna Rada of Ukraine. - 1998, № 27-28, Art. 182

10. I.Yu. Khomyshyn Principle of education's informatization in the conditions of globalization of society // [Electronic resource]. - Access mode: file://C:/Users/ASUS/Downloads/vnulpurn_2016_850_21\%20(1).pdf

11. Pozhuyev V. I. Shlyakhy i napryamy formuvannya i realizatsiyi suchasnoho informatsiynoho suspil'stva v umovakh hlobalizatsiyi [Ways and directions of forming and implementing modern information society in the conext of globalization]. Humanitarian Bulletin Zaporozhye State Engineering Academy. 2011. Vol. 46. pp. 5-18.

12. Kryvonos O.M. Використання інформаційно-комунікаційних технологій в навчанні: навчальний посібник. - Zhytomyr : Publisher Zhytomyr Ivan Franko State University, 2012. - 182 p.

13. Kovalenko, A.A. and Kuchuk, G.A. (2018), "The current state and trends of the development of computer systems of objects of critical application", Systems of control, navigation and communication, PNTU, Poltava, No. 1 (47), pp. 110-113. DOI : https://doi.org/10.26906/SUNZ.2018.1.110.

14. Ruban, I., Kuchuk, H. and Kovalenko A. (2017), "Redistribution of base stations load in mobile communication networks", Innovative technologies and scientific solutions for industries, No 1 (1), P. 75-81, doi : https://doi.org/10.30837/25229818.2017.1.075.

15. Kuchuk, G., Nechausov, S. and Kharchenko, V. (2015), "Two-stage optimization of resource allocation for hybrid cloud data store", International Conference on Information and Digital Technologies, Zilina, pp. 266-271, DOI: http://dx.doi.org/10.1109/DT.2015.7222982

16. Saravana Balaji B., Karthikeyan N.K., Raj Kumar R.S. Fuzzy service conceptual ontology system for cloud service recommendation. Computers \& Electrical Engineering, 2018. Vol.69, P. 435-446, DOI: https://doi.org/10.1016/i.compeleceng.2016.09.013

17. Saravana Balaji B., Karthikeyan N.K., Raj Kumar R.S. Fuzzy service conceptual ontology system for cloud service recommendation. Computers \& Electrical Engineering, 2018. Vol.69, P. 435-446, DOI: https://doi.org/10.1016/j.compeleceng.2016.09.013

18. Saravana Balaji B, Mohamed Uvaze Ahamed, Eswaran C, Kannan R, "Prediction-based Lossless Image Compression", Lecture Notes in Computational Vision and Biomechanics (Springer), Volume 30, No 1, 2019, pp.1749 - 17961, DOI: https://doi.org/10.1007/978-3-030-00665-5_161 
19. Amin Salih M., Potrus M.Y._A Method for Compensation of TCP Throughput Degrading During Movement Of Mobile Node. ZANCO Journal of Pure and Applied Sciences. 2015. Vol. 27, No 6. P. 59-68.

20. Mohammed, A. S. Optimal Forecast Model for Erbil Traffic Road Data. ZANCO Journal of Pure and Applied Sciences. 2017. Vol. 29, No 5. P._137-145. DOI: https://doi.org/10.21271/ZJPAS.29.5.15

21. Gomathi B, Karthikeyan N K, Saravana Balaji B, "Epsilon-Fuzzy Dominance Sort Based Composite Discrete Artificial Bee Colony optimization for Multi-Objective Cloud Task Scheduling Problem”, International Journal of Business Intelligence and Data Mining, Volume 13, Issue 1-3, 2018, pages 247-266, DOI: https://doi.org/10.1504/IJBIDM.2018.088435

22. Sivaram, M., Porkodi, V., Mohammed, A.S., Manikandan V. Detection of Accurate Facial Detection Using Hybrid Deep Convolutional Recurrent Neural Network. ICTACT Journal on Soft Computing. 2019. Vol. 09, Issue 02. pp. 1844-1850. DOI: 10.21917/ijsc.2019.0256

23. Sivaram M., Yuvaraj D., Amin Salih Mohammed, Porkodi, V., ManikandanV. The Real Problem Through a Selection Making an Algorithm that Minimizes the Computational Complexity. International Journal of Engineering and Advanced Technology. 2018. Vol. 8, iss. 2. pp. 95-100.

24. Кучук Г. А. Модель процесса эволюции топологической структуры компьютерной сети системы управления объектом критического применения / Г.А. Кучук, А.А. Коваленко, А.А. Янковский // Системи обробки інформації. 2014. - № 7(123). - C. 93-96.

25. Ruban, I. Redistribution of base stations load in mobile communication networks / I. Ruban, H. Kuchuk, A. Kovalenko // Innovative technologies and scientific solutions for industries. -2017 . - No 1 (1) - P. 75-81. DOI : https://doi.org/10.30837/2522-9818.2017.1.075.

26. Donets, V., Kuchuk, N. and Shmatkov, S. (2018), "Development of software of e-learning information system synthesis modeling process", Advanced Information Systems, Vol. 2, No 2, pp. 117-121, DOI: https://doi.org/10.20998/25229052.2018.2.20.

27. Zykov, I.S., Kuchuk, N.H. and Shmatkov S.I. (2018), "Synthesis of architecture of the computer transaction management system e-learning", Advanced Information Systems, Vol. 2, No. 3, pp. 60-66, DOI: https://doi.org/10.20998/25229052.2018.3.10

28. Perstok T. M. Dystantsiyna osvita: modernizatsiya shkil'noyi osvity orhanamy mistsevoho samovryaduvannya [Distance education:modernization of school education by local authorities]. 2014. T. 15. Vol. 291. pp. 366-375.

29. Pozhuiev V.I. Ways and directions of formation and realization of modern information society in globalization / V.I. Pozhuiev // Bulletin of Zaporizhzhya State Engineering Academy. - 2011. - Ed. 46. - P. 5-18.

Рецензент: д-р техн. наук, доц. О. В. Шефер, Полтавський національний технічний університет імені Юрія Кондратюка, Полтава Received (Надійшла) 23.04.2019

Accepted for publication (Прийнята до друку) 29.05.2019

\section{Сучасні інформаційні технології як основа процесу інформатизації освіти}

А. М. Гафіяк, С. П.. Альошин, О. О.Бородіна, А. О. Дяченко-Богун

Стаття присвячена аналізу і дослідженню інноваційних методів навчання студентів в умовах розвитку індустрії інформаційних технологій. Проаналізовано актуальні проблеми професійної підготовки фахівців в умовах розвитку інформаційного суспільства та досліджено шляхи їх вирішення. Проаналізовано роль інформаційних технологій в закладах вищої освіти. На даний час основними напрямками в навчальному процесі $є$ використання автоматизованих систем і комплексів, експертних систем і систем підтримки рішень, освоєння інформаційних технологій з використання інформаційних технологій для моделювання різних об’єктів і процесів. Досліджено види інноваційних методів навчання 3 використанням сучасних технологій. На цьому етапі використовують потужні персональні комп'ютера, нові інформаційні та телекомунікаційні технології. Досліджено особливості технічних та програмних засобів навчального призначення. Одними із особливих засобів навчання $\epsilon$ доступність, швидкість отримання знань у зручний час, можливість індивідуального темпу набуття знань. Обгрунтовано напрямки використання інформаційних технологій у навчальному середовищі.

Ключові слова: програмні засоби, інноваційні методи навчання, інформаційні технології, педагогічні інновації.

\section{Современные информационные технологии как основа процесса информатизации образования}

А. М. Гафияк, С. П. Алёшин, Е. А. Бородина, А. О. Дяченко-Богун

Статья посвящена анализу и исследованию инновационных методов обучения студентов в условиях развития индустрии информационных технологий. Проанализированы актуальные проблемы профессиональной подготовки специалистов в условиях развития информационного общества и исследованы пути их решения. Проанализирована роль информационных технологий в учреждениях высшего образования. В настоящее время основными направлениями в учебном процессе является использование автоматизированных систем и комплексов, экспертных систем и систем поддержки решений, освоение информационных технологий по использованию информационных технологий для моделирования различных объектов и процессов. Исследованs виды инновационных методов обучения с использованием современных технологий. На этом этапе используют мощные персональные компьютера, новые информационные и телекоммуникационные технологии. Исследованы особенности технических и программных средств учебного назначения. Одними из особых средств обучения является доступность, скорость получения знаний в удобное время, возможность индивидуального темпа приобретения знаний. Обоснованы направления использования информационных технологий в учебной среде.

Ключевые слова: программные средства, инновационные методы обучения, информационные технологии, педагогические инновации. 